\title{
モリブデンおよびタングステンを含む アルミニウム合金の再結晶についで*
}

久 笠 敏 ${ }^{* *}$

Satoshi Kugasa: On the Recrystallization of Aluminium Alloys Containing Molybdenum and Tungsten. The effect of addition of Mo or W micro powder on the recrystallization behaviour of cold-rolled $\mathrm{Al}$ and $\mathrm{A} 1-2 \% \mathrm{Mg}$ alloy has been studied by means of hardness measurement and microscopy. The results obtained were as follows: (1) The recry-. stallization temperature in $\mathrm{Al}$ and $\mathrm{Al}-\mathrm{Mg}$ alloy: rose slightly with the increase of the amount of added Mo or $\mathrm{W}$ till the content reached a certain critical amount, as shown in Table 2 . When the content is larger than this critical value, however, the recrystallization temperature became almost constant. (2) The size of the recrystallized grains become progressively finer with addition of Mo or $\mathrm{W}$ till the content of Mo or $\mathrm{W}$ reaches $0.3 \sim 0.5 \% \mathrm{Mo}$ or $\mathrm{W}$ in $\mathrm{Al}$, and $0.05 \sim 0.1 \% \mathrm{Mo}$ or $0.2 \sim 0.3 \% \mathrm{~W}$ in $\mathrm{Al}-\mathrm{Mg}$ alloy. In the specimens with $\mathrm{Mo}$ or $\mathrm{W}$ of more than this content, however, the recrystallized grains are fairly fine and almost constant against the change of final annealing temperature as well as cold-rolling reduction of more than medium degree, also free of influence from the variation of the preliminary annealing temperature. (3) The recrystallization diagrams of $\mathrm{Al}$ and $\mathrm{Al}-\mathrm{Mg}$ alloy containing Mo or W have been studied, as shown in Fig.3,Fig.4, Fig.5 and Fig.6.

(Received April 10, 1961)

\section{I. 緒 呾}

$\mathrm{A} 1$ および $\mathrm{A} 1$ 合金に Mo 或いは W の微粒子を添加する と鋳造組織を著しく微細化することはよく知られてい る(1)(2). しかし冷間加工後の再結晶に及ぼす影響について の研究は少い(3) (4).よつて $\mathrm{A} 1$ 怙よび $\mathrm{A} 1-\mathrm{Mg}$ 合金に $\mathrm{Mo}$ 或 いはW を添加して, これらの金属の微粒子が 再結晶温度 に及ぼす影響, および拝延率一燃鈍温度一再結晶粒度の関係 を得るための研究を行なつた。

\section{II. 実 験 方 法}

試料の製作に使用した原料の純度は， $\mathrm{A} 199.9 \%, \mathrm{Mg}$ ， Mo 抢よび W ともに $99.5 \%$ である. A1-Mo系および A1$\mathrm{W}$ 系合金は Mo 或いは $\mathrm{W}$ を約 $0.05 \sim 0.5 \%$ の範囲内に 5 種類, $\mathrm{A} 1-\mathrm{Mg}-\mathrm{Mo}$ 或いは $\mathrm{W}$ 系合金は $\mathrm{Mg}$ 含有量を $2 \%$ に

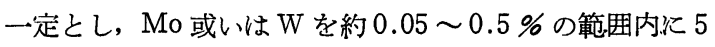
種類を選んだ．Mo扣よび-W の添加にはこれら金属粉末を $\mathrm{A} 1$ 溶湯に添加し熔製したA1-0.81\% Mo および A1-1.05\% W の鋳塊によつた. 試料の化学組成は Table 1 亿示す. 試料用の鋳塊の製作に括ける熔解温度は $740 \sim 970^{\circ} \mathrm{C}$, 鋳込 温度は $700 \sim 950^{\circ} \mathrm{C}$ であり, $17 \times 50 \times 150 \mathrm{~mm}$ の常温金型 に鋳造した。鋳塊は $520^{\circ} \mathrm{C}, 6 \mathrm{hr}$ の均熱を行なつた後二分 し, 一部は化学分析試料, 他の部は压延試料とした。板の 製作には熱間圧延により $5 \mathrm{~mm}$ 厚 (压延温度約 $500 \sim 400^{\circ} \mathrm{C}$ ),

** 広島大学工学部

* 1959 年 10 月本会大阪大会 打よび 1960 年 4 月本会 東京大会江一部発表

(1) L.F. Mondolfo and F.A.Crossley: J. Metals, 3 (1951), 114?

(2) V. De Piere and H. Bernstein: Iron Age, 20 (1949) , 162.

(3) H.Hushuka and H. Nowotny: Metall, 12 (1958), 6.

（4）中村,松尾,柳沢：1955 年 10 月本会東京大会飞講演.
ついで泠間圧延により $2.5 \mathrm{~mm}$ 厚とし, 切半して一部は $400^{\circ} \mathrm{C}$ 或いは $370^{\circ} \mathrm{C}, 3 \mathrm{hr}$, 他部は $550^{\circ} \mathrm{C}, 3 \mathrm{hr}$ の中間焼釶

Table 1 Analysis of the specimens.

\begin{tabular}{l|c|c|c}
\hline & \multicolumn{3}{|c}{ Analysis (\%) } \\
\cline { 2 - 4 } Specimens & Mg & Mo & W \\
\hline A1-0.05Mo & - & 0.060 & - \\
A1-0.1 Mo & - & 0.13 & - \\
A1-0.2 Mo & - & 0.20 & - \\
A1-0.3 Mo & - & 0.34 & - \\
A1-0.5 Mo & - & 0.55 & - \\
\hline A1-2Mg & 2.19 & $\ldots$ & - \\
A1-2Mg-0.05Mo & 2.15 & 0.044 & - \\
A1-2Mg-0.1 Mo & 2.17 & 0.097 & - \\
A1-2Mg-0.2 Mo & 2.19 & 0.19 & - \\
A1-2Mg-0.3 Mo & 2.18 & 0.32 & - \\
A1-2Mg-0.5 Mo & 2.13 & 0.55 & - \\
\hline A1-0.05W & - & - & 0.05 \\
A1-0.1 W & - & - & 0.09 \\
A1-0.2 W & - & - & 0.18 \\
A1-0.3 W & - & - & 0.30 \\
A1-0.5 W & - & - & 0.48 \\
\hline A1-2Mg-0.05 W & 2.10 & - & 0.04 \\
A1-2Mg-0.1 W & 2.11 & - & 0.09 \\
A1-2Mg-0.2 W & 2.15 & - & 0.19 \\
A1-2Mg-0.3 W & 1.98 & - & 0.32 \\
A1-2Mg-0.5 W & 2.09 & - & 0.51 \\
\hline
\end{tabular}

を行なつた．この $2.5 \mathrm{~mm}$ の板汇圧延率 $3,6,10,20,30$ ， 50 および $80 \%$ の各種の冷間压延を行ない，この各くの 连延率の板から $15 \mathrm{~mm}$ 角の試片を採り，塩浴中に括いて $550^{\circ} \mathrm{C}$ までの種々の温度に 30 分間加熱して, 再結晶の様 子を調べた。再結晶粒度の測定には, 王水によつて腐食し て得られふマクロ組織拉よび電解研磨による顕微鏡組織か ら切断法によつて結晶粒の平均直径を求めた。 


\section{III. 実 験 結 果}

\section{1. 再結晶温度}

再結晶開始温度は, 硬度測定による軟化曲線においては 急激に軟化を開始する温度，顕微鏡組織に括いては微小結 晶粒の生ずる温度とし, 再結晶終了温度は軟化曲線におい ては急激な軟化の終了する温度, 顕微鏡組織においては全 体的にほぼ均一な新結晶粒の生ずる温度としたが，各くの 測定值は概ね一致した. Fig.1，2 はそれぞれ A1に Mo あ

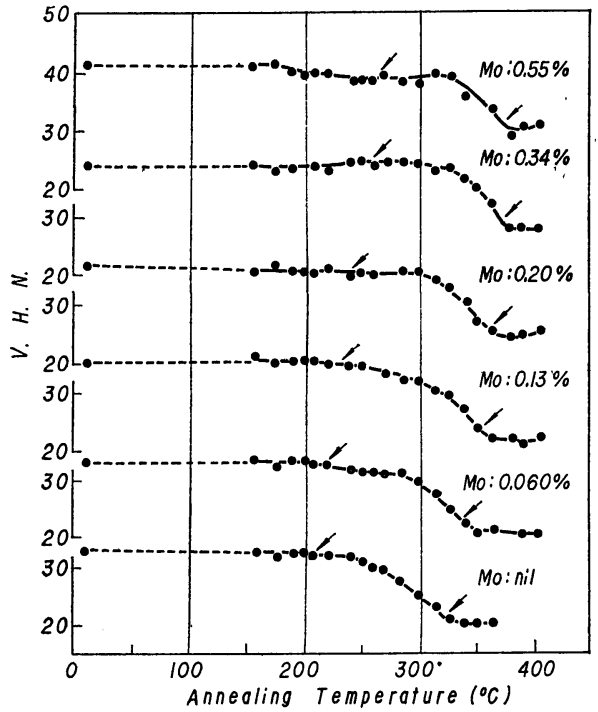

Fig.1 Curves of hardness against annealing temperature for Al-Mo sheet, preliminary annealed at $400^{\circ} \mathrm{C}$, cold rolled $50 \%$, and finally annealed for $30 \mathrm{~min}$.

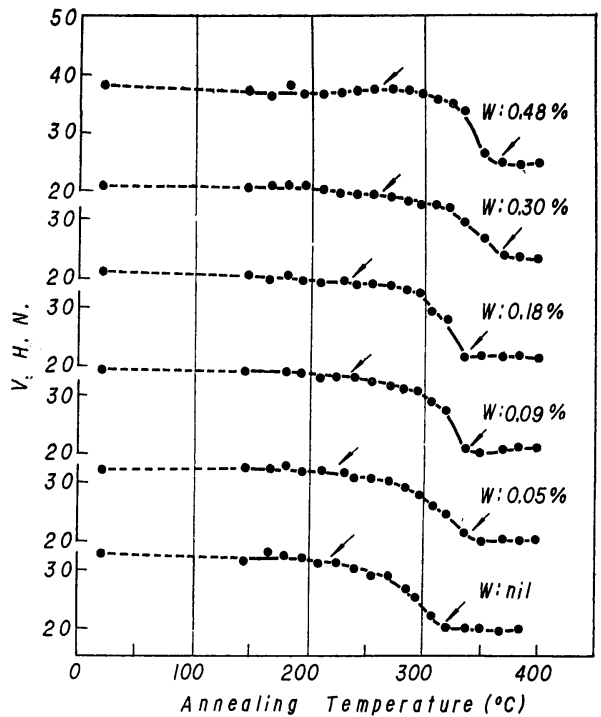

Fig. 2 Curves of hardness against annealing temperature for A1-W sheet, preliminary annealed at $400^{\circ} \mathrm{C}$, cold rolled $50 \%$, and finally annealed for $30 \mathrm{~min}$.

るいは W 添加した試片を $400^{\circ} \mathrm{C}$ 或いは $370^{\circ} \mathrm{C}, 3 \mathrm{hr}$ の 中間焼鈍の後, 圧延率 $50 \%$ の冷開圧延を行ない, 最後に図
の各温度に 30 分間焼鈍した場合の軟化曲線を示す.Table 2 に軟化曲線と顕微鏡組織から定めた 再結晶温度を一括し

Table 2 Initial and final temperature of recrystallization of cold rolled specimens. The preliminary annealing temperature is $400^{\circ} \mathrm{C}$ (A1-Mo, A1-W specimens) or $370^{\circ} \mathrm{C}$ (A1-Mg-Mo, $\mathrm{Al}-\mathrm{Mg}-\mathrm{W}$ specimens) and the rate of reduction by rolling is $50 \%$.

\begin{tabular}{c|c|c|c}
\hline \multicolumn{2}{c|}{ Specimens } & \multicolumn{2}{c}{$\begin{array}{c}\text { Recrystallization } \\
\text { temperature }\end{array}$} \\
\cline { 3 - 4 } Systems & Mo or W\% & Initial & Final \\
\hline \multirow{4}{*}{ A1-Mo } & 0 & $\sim 210$ & $\sim 320$ \\
& 0.060 & $\sim 220$ & $\sim 330$ \\
& 0.13 & $\sim 230$ & $\sim 350$ \\
& 0.20 & $\sim 240$ & $\sim 360$ \\
& 0.34 & $\sim 260$ & $\sim 370$ \\
& 0.55 & $\sim 260$ & $\sim 370$ \\
\hline \multirow{4}{*}{ A1-Mg-Mo } & 0 & $\sim 220$ & $\sim 320$ \\
& 0.044 & $\sim 220$ & $\sim 320$ \\
& 0.097 & $\sim 230$ & $\sim 330$ \\
& 0.19 & $\sim 240$ & $\sim 360$ \\
& 0.32 & $\sim 240$ & $\sim 360$ \\
& 0.55 & $\sim 240$ & $\sim 360$ \\
& 0.05 & $\sim 220$ & $\sim 330$ \\
& 0.09 & $\sim 230$ & $\sim 330$ \\
& 0.18 & $\sim 230$ & $\sim 330$ \\
& 0.30 & $\sim 260$ & $\sim 370$ \\
& 0.48 & $\sim 260$ & $\sim 370$ \\
\hline \multirow{4}{*}{ A1-Mg-W } & 0.04 & $\sim 230$ & $\sim 320$ \\
& 0.09 & $\sim 230$ & $\sim 330$ \\
& 0.19 & $\sim 250$ & $\sim 350$ \\
& 0.32 & $\sim 250$ & $\sim 350$ \\
& 0.51 & $\sim 250$ & $\sim 350$ \\
\hline & & &
\end{tabular}

て示した。これらの実験值から次のような事項が指摘でき る.

(1) A1にMoあるいはWを添加した場合は，再結晶開始 温度执よび終了温度ともに Mo 或いはW 含有量の增加と ともにやや上昇し, Mo 約 $0.20 \sim 0.34 \%, \mathrm{~W}$ 約 $0.18 \sim 0.30$ $\%$ に打いて開始温度は約 $260^{\circ} \mathrm{C}$, 終了温度は約 $370^{\circ} \mathrm{C}$ の 最高を示すが，さらにMo 或いはW を増加するも概ね変 化はない。

(2) Al-Mg 合全に Mo あるいはWを添加した場合にお いても再結晶開始および終了温度ともに Mo 或いは W 含 有量の增加とともに稍ぐ上昇し, 開始温度は Mo 約 0.097 〜 $0.19 \%$ に打いて約 $240^{\circ} \mathrm{C}, \mathrm{W}$ 約 $0.09 \sim 0.19 \%$ に打いて 約 $250^{\circ} \mathrm{C}$, 終了温度は $\mathrm{Mo}$ 約 $0.097 \sim 0.19 \%$ に扣いて約 $360^{\circ} \mathrm{C}, \mathrm{W}$ 約 $0.09 \sim 0.19 \%$ において約 $350^{\circ} \mathrm{C}$ の最高を示す が，さらに Mo 或いは W を増加してむ殆んど変化はない.

\section{2. 再結晶図}

Fig. 3, 4, 5 および 6 は $\mathrm{A} 1$ あるいは $\mathrm{A} 1-\mathrm{Mg}$ 合金にMo あるいはWを添加した試片において，中閒焼鈍温度を低 温として $400^{\circ} \mathrm{C}$ 或いは $370^{\circ} \mathrm{C}$ 牤よび高温として $550^{\circ} \mathrm{C}$ 変 化した時の実験結果を総括した再結晶図である. Table 3 はこれらの再結晶粒度を得るたあたつての初期結晶粒度を 示した. Table 4 には各種試片について, 压延率 $50 \%$ の とさの焼鈍温度による再結晶粒度を示した. Photo. 1, 2, 
3 および 4 は $\mathrm{A} 1-\mathrm{Mg}$ 合金に $0.19 \% \mathrm{Mo}$ あるいは $0.32 \%$

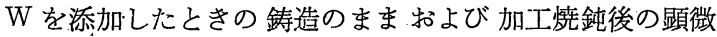

（2）燒鈍温度が低い場合は，Mo或いは W 含有量にか かわらず略 $<$ 同大の再結晶粒が得られるが，焼鈍温度が高

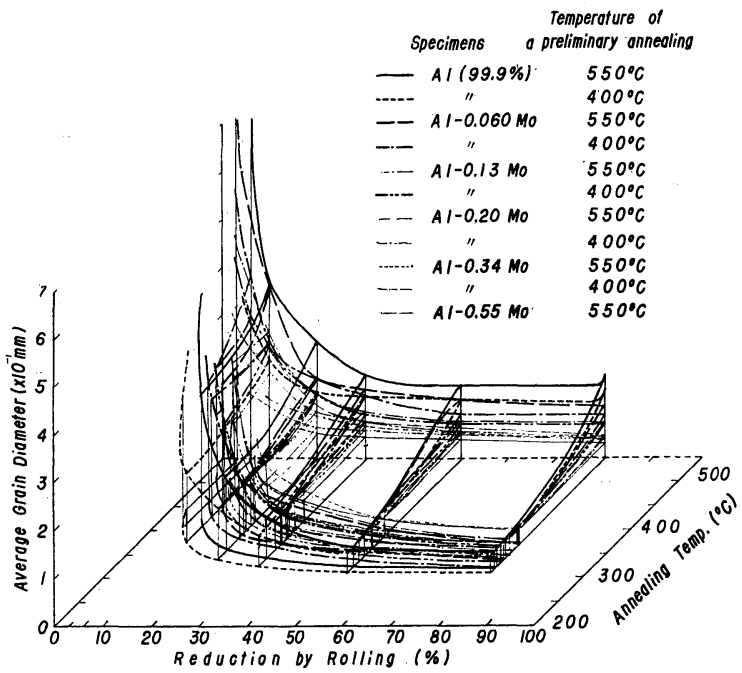

Fig.3 Recrystallization diagram of aluminium containing molybdenum.

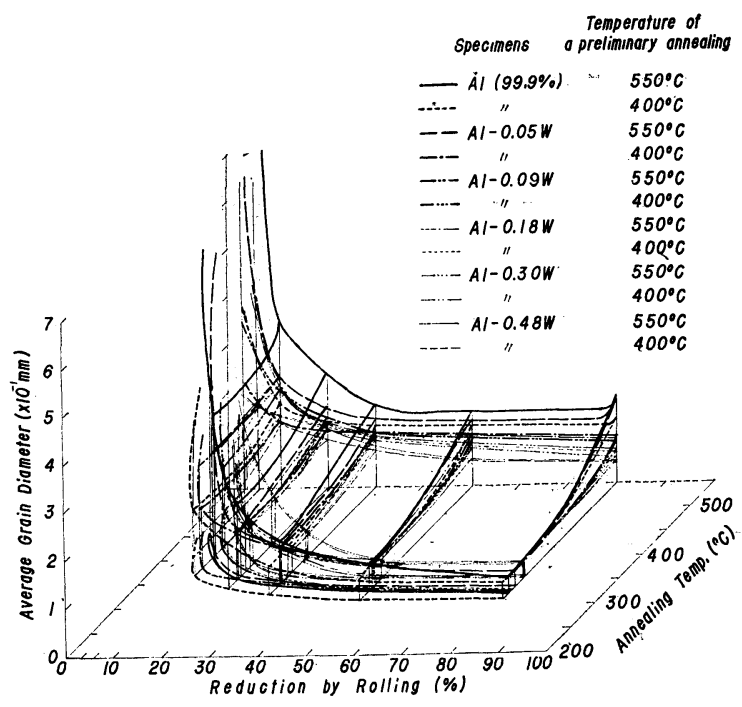

Fig. 5 Recrystallization diagram of aluminium containing tungsten.

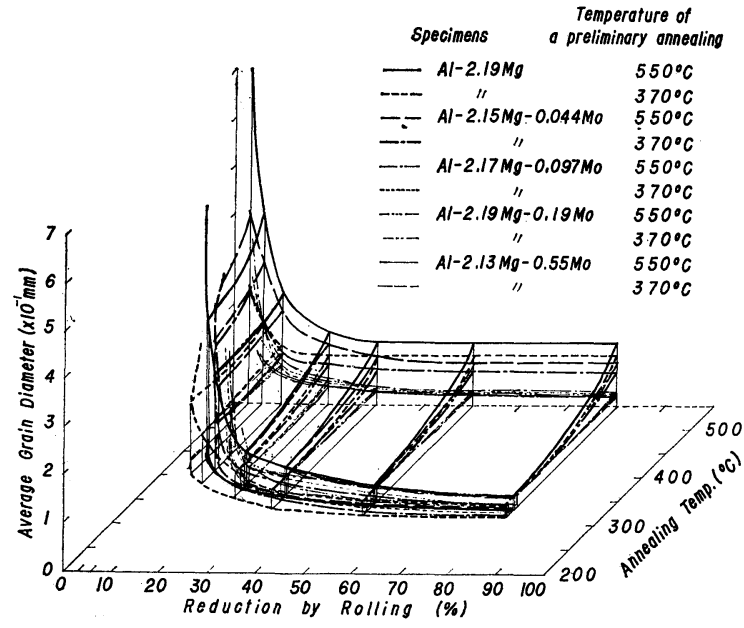

Fig. 4 Recrystallization diagram of the aluminiummagnesium alloys containing molybdenum.

鏡組織を示す．これらの再結晶図扣よび測定結果から，次 の諸事実を指摘することができる。

1.中閶燒釷温度が一定の場会, 再結晶粒度に及ぼす Mo 或いは W 含有量の影響は次のよ5に要約される。

(1) Mo 或いは $\mathrm{W}$ 含有量の增加とともに, 再結晶粒度 は圧延率および焼鈍温度の全般にわたつて小さくなるが， $\mathrm{A} 1$ に $\mathrm{Mo}$ を添加したときは $\mathrm{Mo}$ 約 $0.3 \sim 0.5 \%$ 以上， A1$\mathrm{Mg}$ 合金汇 Mo を添加したときは Mo 約 0.05 0.1\%以 上, $\mathrm{A} 1 飞 \mathrm{~W}$ を添加したとさはW 約 0.3 0 0.5\% 以上, $\mathrm{A} 1-\mathrm{Mg}$ 合金に W を添加したときは $\mathrm{W}$ 約 $0.2 \sim 0.3 \%$ 以上 を含有すると，中程度以上の压延率に扣いては著しい变化 は認められない。

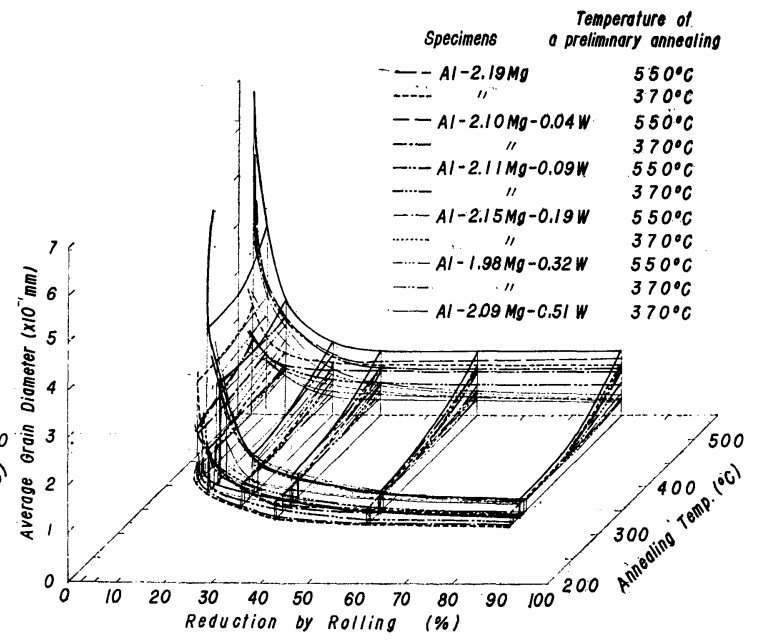

Fig. 6 Recrystallization diagram of the aluminiummagnesium alloys containing tungsten.

くなると，含有量の增加ととも汇再結晶粒度は顕著厄小さ くなり，各系合金とるに(1)項炕示した含有量汇到ると,中 程度以上の压延率に招いては, 焼鈍温度にかかわりなく, 再結晶粒は $0.02 \sim 0.05 \mathrm{~mm}$ 程度のほ济均一な粒度となる。 しかしとれ以上の Mo 或いは Wを添加するも著しい変化 は認められない。

2. 中間焼鈍温度を变化した場合の影響については次の ように要約される。

(1) 焼鈍温度が低い時は, 中間焼鈍温度の高低にかかわ りなく, 中程度以上の圧延率の再結晶粒度には著しい差異 は生じない。

（2）焼鈍温度が高くなると，A1にMoを添加したときは 
$\mathrm{Mo}$ 約 $0.3 \sim 0.5 \%$ まで, $\mathrm{A} 1-\mathrm{Mg}$ 合金飞 Mo を添加したと さは Mo 約 0.05〜0.1\%をで， $\mathrm{Al}$ に W を添加したときは

Table 3 Initial grain size caused from various preliminary annealing temperature.

\begin{tabular}{|c|c|c|}
\hline \multirow{2}{*}{ Specimens } & \multicolumn{2}{|c|}{$\begin{array}{l}\text { Initial grain size mm after } \\
\text { prèliminary annealed at }\end{array}$} \\
\hline & $400^{\circ} \mathrm{C}$ or $370^{\circ} \mathrm{C}^{*}$ & $550^{\circ}$ \\
\hline $\begin{array}{l}\text { A1 }(99.9 \%) \\
\text { A1-0.060 Mo } \\
\text { Al-0.13 Mo } \\
\text { A1-0.20 Mo } \\
\text { A1-0.34 Mo } \\
\text { Al-0.55 Mo }\end{array}$ & $\begin{array}{l}0.05 \\
0.05 \\
0.05 \\
0.04 \\
0.04 \\
0.04\end{array}$ & $\begin{array}{l}0.15 \\
0.12 \\
0.08 \\
0.07 \\
0.05 \\
0.05\end{array}$ \\
\hline $\begin{array}{l}\text { A1-2.19Mg } \\
\text { A1-2.15Mg-0.044 Mo } \\
\text { A1-2.17 Mg-0.097 Mo } \\
\text { A1-2.19Mg-0.19 Mo } \\
\text { A1-2.18Mg-0.32 Mo } \\
\text { A1-2.13 Mg-0.55 Mo }\end{array}$ & $\begin{array}{l}0.03 \\
0.03 \\
0.04 \\
0.03 \\
0.03 \\
0.02\end{array}$ & $\begin{array}{l}0.14 \\
0.08 \\
0.04 \\
0.03 \\
0.03 \\
0.03\end{array}$ \\
\hline $\begin{array}{l}\mathrm{A} 1-0.05 \mathrm{~W} \\
\mathrm{~A} 1-0.09 \mathrm{~W} \\
\mathrm{~A} 1-0.18 \mathrm{~W} \\
\mathrm{~A} 1-0.30 \mathrm{~W} \\
\mathrm{~A} 1-0.48 \mathrm{~W}\end{array}$ & $\begin{array}{l}0.05 \\
0.05 \\
0.05 \\
0.04 \\
0.0 .5\end{array}$ & $\begin{array}{l}0.08 \\
0.10 \\
0.08 \\
0.07 \\
0.05\end{array}$ \\
\hline $\begin{array}{l}\mathrm{Al}-2.10 \mathrm{Mg}-0.04 \mathrm{~W} \\
\mathrm{Al}-2.11 \mathrm{Mg}-0.09 \mathrm{~W} \\
\mathrm{Al}-2.15 \mathrm{Mg}-0.19 \mathrm{~W} \\
\mathrm{Al}-1.98 \mathrm{Mg}-0.32 \mathrm{~W} \\
\mathrm{Al}-2.09 \mathrm{Mg}-0.51 \mathrm{~W}\end{array}$ & $\begin{array}{l}0.03 \\
0.03 \\
0.02 \\
0.02 \\
0.02\end{array}$ & $\begin{array}{l}0.13 \\
0.10 \\
0.05 \\
0.04 \\
0.03\end{array}$ \\
\hline
\end{tabular}

* A1-Mo, A1-W specimens have been annealed at $400^{\circ} \mathrm{C}$, and $\mathrm{A} 1-\mathrm{Mg}-\mathrm{Mo}, \mathrm{A} 1-\mathrm{Mg}-\mathrm{W}$ specimens at $370^{\circ} \mathrm{C}$.
場合には，中間焼鈍温度が高いほど再結晶粒度はかなり粗 大となるが，Mo或いはWをこれ以上に含有する時は，中

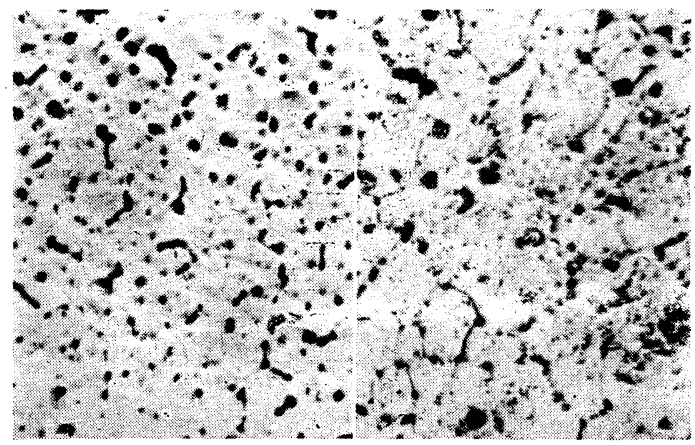

Photo. 1 Microstructure Photo. 2 Microstructure of $\mathrm{A} 1-2.19 \% \mathrm{Mg}-0.19 \%$ of $\mathrm{A} 1-2.19 \% \mathrm{Mg}-0.19 \%$ Mo casting.

$$
\times 100(\times 4)
$$

Mo sheet(Rate of reduc-

tion by rolling: $80 \%$,

annealing temperature :

$550^{\circ} \mathrm{C}$, annealing time:

30 minutes $). \times 200(\times 4)$

間焼鈍温度に関係なく，中程度以上の压延率の再結晶粒度 は略く一定にして微細となる。

これを要するにA1 および $\mathrm{A} 1-\mathrm{Mg}$ 合金の再結晶粒度に及 ぼすMo 或いはW 微粒子の影響としては, Mo 或いは W 添加量の增加ととむに再結晶粒度は著しく小さくなるが， 少量添加の時は, な敃圧延率和よび最終焼鈍温度或いは中 間焼鈍温度の変化によつてかなりの差異が認められる。し かし各系合金につき先に示した一定限度以上に添加する時

Table 4 Recrystallized grain size of the specimens.

\begin{tabular}{|c|c|c|c|c|c|c|c|c|c|c|}
\hline \multirow{3}{*}{ Specimens } & \multicolumn{10}{|c|}{ Grain size $\mathrm{mm}$ after } \\
\hline & \multicolumn{5}{|c|}{$\begin{array}{l}\text { Preliminary annealed at } 400^{\circ} \mathrm{C}(\mathrm{Al}-\mathrm{Mo} \text {, } \\
\mathrm{Al}-\mathrm{W}) \text {, or } 370^{\circ} \mathrm{C} \text { (A1-Mg-Mo, Al-Mg-W), } \\
\text { cold rolled } 50 \% \text { and finally annealed at }\end{array}$} & \multicolumn{5}{|c|}{$\begin{array}{l}\text { Preliminary annealed at } 550^{\circ} \mathrm{C} \text {, cold } \\
\text { rolled } 50 \% \text { and finally annealed at }\end{array}$} \\
\hline & $350^{\circ} \mathrm{C}$ & $400^{\circ} \mathrm{C}$ & $450^{\circ} \mathrm{C}$ & $500^{\circ} \mathrm{C}$ & $550^{\circ} \mathrm{C}$ & $350^{\circ} \mathrm{C}$ & $400^{\circ} \mathrm{C}$ & $450^{\circ} \mathrm{C}$ & $500^{\circ} \mathrm{C}$ & $550^{\circ} \mathrm{C}$ \\
\hline $\begin{array}{l}\text { A1 } \\
\text { Al-0.060Mo } \\
\text { Al-0.13 Mo } \\
\text { Al-0.20 Mo } \\
\text { A1-0.34 Mo } \\
\text { Al-0.55 Mo }\end{array}$ & $\begin{array}{l}0.04 \\
0.04 \\
0.04 \\
- \\
- \\
-\end{array}$ & $\begin{array}{l}0.05 \\
0.05 \\
0.05 \\
0.06 \\
0.05 \\
0.04\end{array}$ & $\begin{array}{l}0.06 \\
0.07 \\
0.06 \\
0.06 \\
0.04 \\
0.04\end{array}$ & $\begin{array}{l}0.08 \\
0.08 \\
0.06 \\
0.07 \\
0.05 \\
0.04\end{array}$ & $\begin{array}{l}0.12 \\
0.09 \\
0.07 \\
0.06 \\
0.05 \\
0.04\end{array}$ & $\begin{array}{l}0.04 \\
= \\
= \\
-\end{array}$ & $\begin{array}{l}0.06 \\
0.07 \\
0.05 \\
0.06 \\
0.05 \\
0.04\end{array}$ & $\begin{array}{l}0.08 \\
0.08 \\
0.05 \\
0.06 \\
0.05 \\
0.04\end{array}$ & $\begin{array}{l}0.10 \\
0.10 \\
0.08 \\
0.06 \\
0.06 \\
0.04\end{array}$ & $\begin{array}{l}0.15 \\
0.13 \\
0.08 \\
0.07 \\
0.06 \\
0.04\end{array}$ \\
\hline $\begin{array}{l}\text { Al-2.19 Mg } \\
\text { Al-2.15Mg-0.044 Mo } \\
\text { Al-2.17Mg-0.097 Mo } \\
\text { Al-2.19Mg-0.19 Mo } \\
\text { Al-2.18Mg-0.32 Mo } \\
\text { Al-2.13Mg-0.55 Mo }\end{array}$ & $\begin{array}{l}0.03 \\
0.03 \\
0.03 \\
- \\
-\end{array}$ & $\begin{array}{l}0.03 \\
0.04 \\
0.03 \\
0.02 \\
0.02 \\
0.02\end{array}$ & $\begin{array}{l}0.04 \\
0.04 \\
0.03 \\
0.03 \\
0.02 \\
0.02\end{array}$ & $\begin{array}{l}0.06 \\
0.05 \\
0.04 \\
0.03 \\
0.03 \\
0.03\end{array}$ & $\begin{array}{l}0.10 \\
0.07 \\
0.03 \\
0.03 \\
0.03 \\
0.03\end{array}$ & $\begin{array}{l}0.03 \\
0.03 \\
- \\
= \\
-\end{array}$ & $\begin{array}{l}0.05 \\
0.04 \\
0.04 \\
0.03 \\
0.02 \\
0.02\end{array}$ & $\begin{array}{l}0.06 \\
0.05 \\
0.04 \\
0.03 \\
0.02 \\
0.02\end{array}$ & $\begin{array}{l}0.08 \\
0.06 \\
0.04 \\
0.03 \\
0.03 \\
0.02\end{array}$ & $\begin{array}{l}0.13 \\
0.09 \\
0.04 \\
0.03 \\
0.03 \\
0.02\end{array}$ \\
\hline $\begin{array}{l}\text { A1-0.05W } \\
\text { Al-0.09 W } \\
\text { A. }-0.18 \mathrm{~W} \\
\text { A1-0.30W } \\
\text { A1-0.48 W }\end{array}$ & $\begin{array}{l}0.03 \\
0.04 \\
0.04 \\
-\end{array}$ & $\begin{array}{l}0.05 \\
0.05 \\
0.04 \\
0.05 \\
0.04\end{array}$ & $\begin{array}{l}0.05 \\
0.05 \\
0.05 \\
0.05 \\
0.05\end{array}$ & $\begin{array}{l}0.07 \\
0.07 \\
0.06 \\
0.06 \\
0.06\end{array}$ & $\begin{array}{l}0.10 \\
0.10 \\
0.09 \\
0.09 \\
0.06\end{array}$ & $\begin{array}{l}0.04 \\
= \\
=\end{array}$ & $\begin{array}{l}0.05 \\
.0 .05 \\
0.05 \\
0.05 \\
0.04\end{array}$ & $\begin{array}{l}0.07 \\
0.08 \\
0.06 \\
0.06 \\
0.04\end{array}$ & $\begin{array}{l}0.11 \\
0.08 \\
0.08 \\
0.06 \\
0.05\end{array}$ & $\begin{array}{l}0.13 \\
0.13 \\
0.10 \\
0.09 \\
0.05\end{array}$ \\
\hline $\begin{array}{l}\text { A1-2.10Mg-0.04 W } \\
\text { Al-2.11 Mg-0.09W } \\
\text { A1-2.15Mg-0.19W } \\
\text { Al-1.98Mg-0.32 W } \\
\text { A1-2.09Mg-0.51 W }\end{array}$ & $\begin{array}{l}0.03 \\
0.03 \\
0.03 \\
0.02 \\
0.02\end{array}$ & $\begin{array}{l}0.03 \\
0.03 \\
0.02 \\
0.03 \\
0.02\end{array}$ & $\begin{array}{l}0.04 \\
0.03 \\
0.03 \\
0.02 \\
0.03\end{array}$ & $\begin{array}{l}0.06 \\
0.04 \\
0.03 \\
0.02 \\
0.03\end{array}$ & $\begin{array}{l}0.08 \\
0.05 \\
0.04 \\
0.04 \\
0.03\end{array}$ & $\begin{array}{l}0.03 \\
0.03 \\
0.03 \\
0.03 \\
0.03\end{array}$ & $\begin{array}{l}0.04 \\
0.04 \\
0.04 \\
0.03 \\
0.03\end{array}$ & $\begin{array}{l}0.05 \\
0.05 \\
0.04 \\
0.04 \\
0.03\end{array}$ & $\begin{array}{l}0.06 \\
0.06 \\
0.04 \\
0.03 \\
0.03\end{array}$ & $\begin{array}{l}0.11 \\
0.08 \\
0.06 \\
0.05 \\
0.03\end{array}$ \\
\hline
\end{tabular}

$\mathrm{W}$ 約 0.3 0.5\%までA1-Mg 合金にW W添加したときは $\mathrm{W}$ 約 $0.2 \sim 0.3 \%$ までは, Mo 或いは W 含有量が一定の
は,中程度以上の王延率に捈いていは,これらの変化に関係な く, 始終ほぼ一定にしてかつ微細な再結晶粒が得られる. 


\section{IV. 総 括}

A1 江 Mo 或いはW $0.05 \sim 0.5 \%, A 1-2 \% \mathrm{Mg}$ 合金に

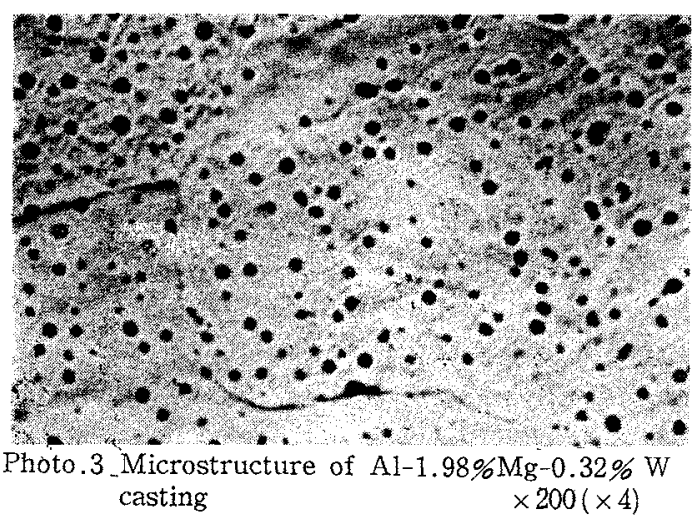

Mo 或 はいW 0.05 0.5\%添加して, 冷開压延後の再 結晶晛象に及代すMo或いはW 微粒于の影響を調べた。 得られた結果を総括すると次のようになる。

(1) Al 扣よび Al-Mg 合金に括いては, Mo 或いはWの 添加量の增加ととるに, 再結晶温度は若干上界する。しか しそれも，A1では再結晶開始温度敊よび終了温度ともに， Moは約 $0.20 \sim 0.34 \%, W$ は約 $0.18 \sim 0.30 \%$ までであ ๖, Al-Mg 合金では, $\mathrm{Mo}$ 約 $0.097 \sim 0.19 \%, \mathrm{~W}$ 約 0.09 〜 0.19\%までであって，これ以上さらに添加するる殆ん ど変化的認められない。

(2) A1，A1-Mg 合金ともに, Mo 或いは W 添加量の增 加ととあに, 再結晶粒度は著しく微細となる。しかし々れ
も'AlにMoを添加した時は $\mathrm{Mo}$ 的 $0.3 \sim 0.5 \%, \mathrm{~A} 1 \mathrm{-Mg}$ 合金汇 Mo 学添加した時は Mo 䄪 $0.05 \sim 0.1 \%, A 1 飞 W$ を添加 した時

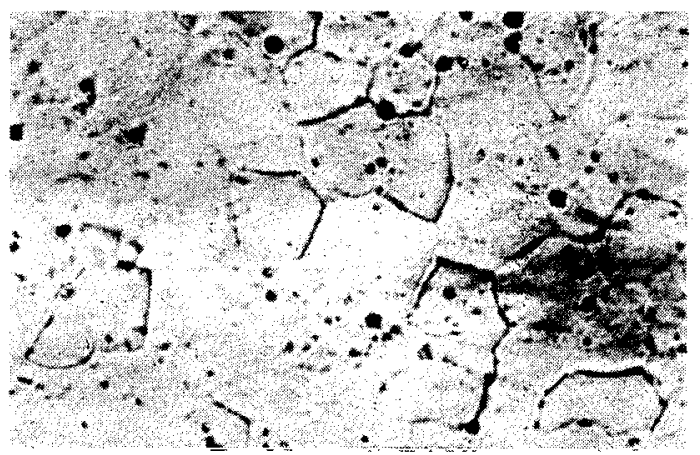

Photo.4 Microstructure of A1-1.98\% Mg-0.32\% W sheet (Rate of reduction by rolling: $80 \%$, annealing temperature $: 550^{\circ} \mathrm{C}$, annealing time $: 30$ minutes) . $\times 200(\times 4)$

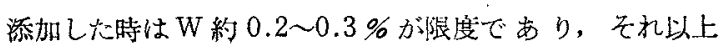
を添加するも顕著な差異は認め難い。

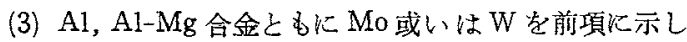
た含有量以上に添加するときは，中程度以上の压延率沈拉

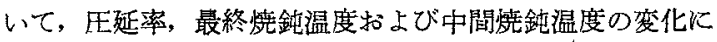
かかわりなく, 常に0.02 0.05 mm 程度の比較的均一汇 して微紐な再結晶粒が得られる。

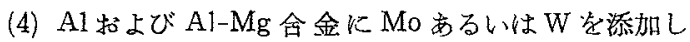
一再結晶図を求めて; Fig. 3，4，5括よび6を得た。

終りに, この研究の実施沈あたうて, 始終御指導と御鞭 撻を頂いた恩師 東北大学教授 大日方一司先生源〈謝意 を表します。 